\title{
Neurosarcoidosis presenting as a large dural mass lesion
}

\author{
Deepa Dash, ${ }^{1}$ Inder Puri, ${ }^{1}$ Manjari Tripathi, ${ }^{1}$ Madakasira Vasantha Padma ${ }^{2}$
}

${ }^{1}$ Department of Neurology, All India Institute of Medical Sciences, New Delhi, India ${ }^{2}$ All India Institute of Medical Sciences, New Delhi, Delhi, India

\section{Correspondence to}

Professor Madakasira Vasantha Padma, vasanthapadma123@ gmail.com

Accepted 25 October 2016
CrossMark

To cite: Dash D, Puri I, Tripathi M, et al. BMJ Case Rep Published online: [please include Day Month Year] doi:10.1136/bcr-2016216793

\section{DESCRIPTION}

A woman aged 52 years presented with episodic holocranial headaches with recurrent episodes of diminution of vision in the right eye and decreased sensation on the right side of face for the past 1 year. Clinical examination revealed optic atrophy in the right eye and sensory loss on the ophthalmic and maxillary division of the trigeminal nerve. MRI brain revealed extensive nodular enhancement on T1-weighted contrast images predominantly involving the dura around bilateral temporal lobes, right fronto-basal area and bilateral cavernous sinuses (figure 1). CT scan of the chest showed multiple lung nodules and mediastinal lymphadenopathy. Cerebrospinal fluid examination, cryptococcal antigen, vasculitic screen, HIV serology and serum ACE levels were all in normal range.

As MRI brain demonstrated extensive thickening of the dura mater, the possible differentials of tuberculous, non-infectious inflammatory causes like sarcoidosis and meningioma en plaque was kept. Dural biopsy was performed which revealed numerous discrete epithelioid cell granulomas along with foreign body and Langhans type of giant cells with negative staining for acid-fast bacilli and fungus, consistent with a diagnosis of sarcoidosis (figure 2). The patient was treated with steroids. During follow-up, the patient was headache-free and facial sensation recovered, but her vision did not improve.

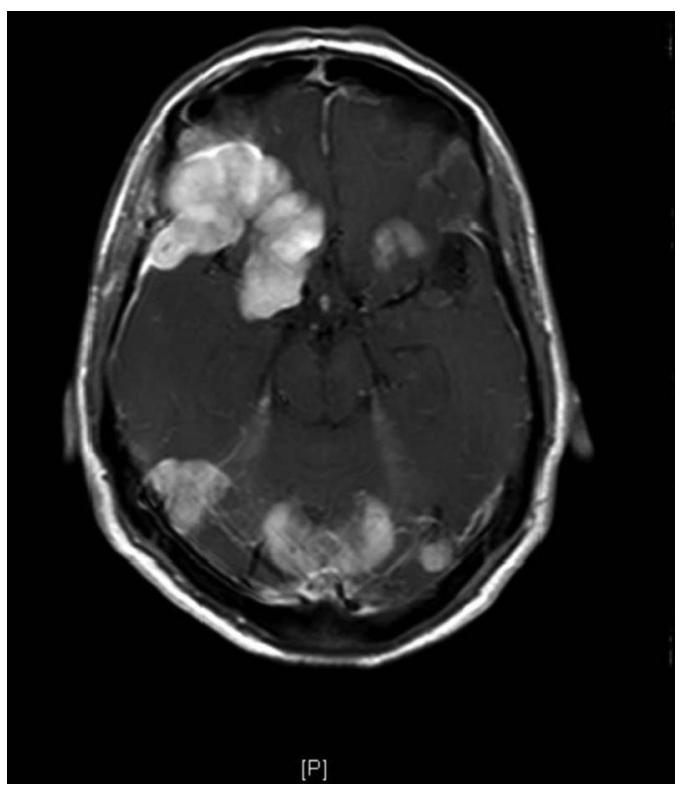

Figure 1 MRI brain, axial section, T1-weighted image showing contrast enhancement involving the dura around bilateral temporal lobes, right fronto-basal area and bilateral cavernous sinuses.

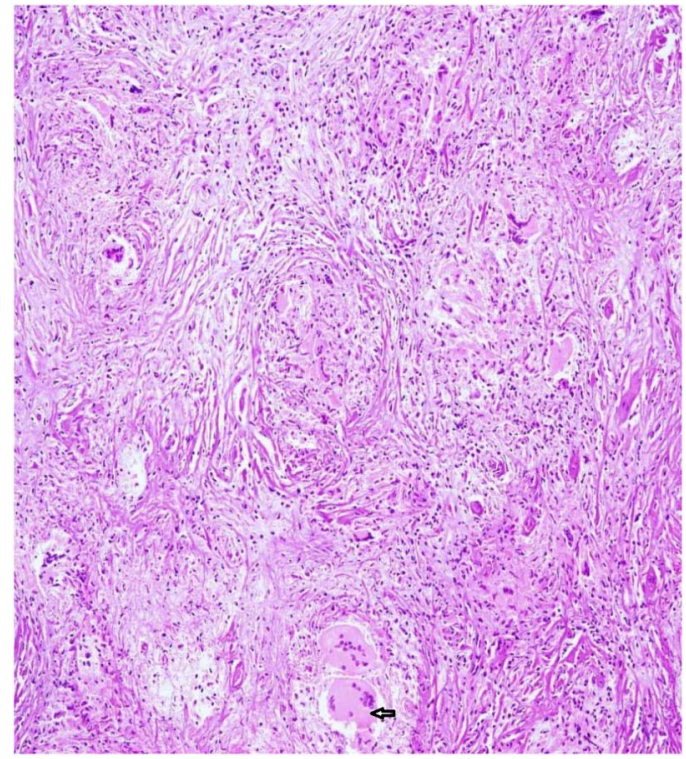

Figure 2 Dural biopsy H\&E stain showed non-caseating granuloma with Langhans-type giant cells.

Dural involvement by sarcoidosis can present as focal dural mass or diffuse dural thickening. These lesions typically enhance homogeneously on contrast-enhanced T1-weighted images and are hypointense on T2-weighted images. In our patient, there was extensive nodular thickening and enhancement of the dura which gave an impression of a tumour but biopsy of dura helped in confirming the diagnosis. Extensive tumour-like involvement of the meninges due to sarcoidosis is rarely reported. ${ }^{12}$ In patients presenting with dural mass, a possibility of sarcoidosis should be kept in mind and all efforts should be made to obtain histopathological confirmation.

\section{Learning points}

- Neurosarcoidosis can present like a mass lesion.

- All efforts should be made to obtain a biopsy and confirm with histopathological diagnosis.

Contributors All the authors agree to the order of authorship and have contributed in the following aspect of the article: DD and IP contributed to data collection; DD is responsible for drafting the article; MT and MVP is responsible for critical revision of the article; MVP is responsible for final approval of the version to be published

Competing interests None declared.

Patient consent Obtained.

Provenance and peer review Not commissioned; externally peer reviewed. 


\section{REFERENCES}

1 Strickland-Marmol LB, Fessler RG, Rojiani AM. Necrotizing sarcoidgranulomatosis mimicking an intracranial neoplasm: clinicopathologic features and review of the literature. Mod Pathol 2000;13:909-13.
2 Leiba H, Siatkowski RM, Culbertson WW, et al. Neurosarcoidosis presenting as an intracranial mass in childhood. J Neuroophthalmol 1996;16: 269-73.

Copyright 2016 BMJ Publishing Group. All rights reserved. For permission to reuse any of this content visit http://group.bmj.com/group/rights-licensing/permissions.

BMJ Case Report Fellows may re-use this article for personal use and teaching without any further permission.

Become a Fellow of BMJ Case Reports today and you can:

- Submit as many cases as you like

- Enjoy fast sympathetic peer review and rapid publication of accepted articles

- Access all the published articles

- Re-use any of the published material for personal use and teaching without further permission

For information on Institutional Fellowships contact consortiasales@bmjgroup.com

Visit casereports.bmj.com for more articles like this and to become a Fellow 